\title{
Application of ecological indicators in coastal watershed under high pressure during summer period
}

\section{Aplicação de indicadores ecológicos em bacia costeira sob elevada pressão da atividade de veraneio}

\author{
Aichely Rodrigues da Silva ${ }^{1}$, Alessandra Larissa D' Oliveira Fonseca ${ }^{1}$, Claudinei José Rodrigues ${ }^{2}$ and \\ Ângela da Veiga Beltrame ${ }^{1}$ \\ ${ }^{1}$ Universidade Federal de Santa Catarina, Florianópolis, SC, Brazil \\ ${ }^{2}$ Instituto Chico Mendes de Conservação da Biodiversidade, Florianópolis, SC, Brazil \\ E-mails: aichely@hotmaill.com (ARS), alarissa.fonseca@gmail.com (ALOF), claudinei.rodrigues@icmbio.gov.br(CJR), \\ angelavbeltrame@gmail.com (AVB)
}

Received: July 10, 2015 - Revised: February 14, 2016 - Accepted: April 05, 2016

\begin{abstract}
Water bodies located in coastal areas are subject to human pressures and the loss of environmental quality. The objective of this study was to evaluate the environmental quality of the river Papaquara through water quality and river landscape, using the Trophic Index (TRIX) and Rapid Assessment Protocol (RAP). The study was developed in the watershed located in the north of the island of Santa Catarina, Florianópolis - SC, whose population increase in the summer is around 280\%. The Trophic Index and the Rapid Assessment Protocol were evaluated in the pre-summer period, summer and after-summer in seven sample points along the inner areas (higher population density), median and outside the Papaquara river, plus two points in affluent. The river Papaquara showed up in great stress state, is classified as eutrophic, $77 \%$ of the samples and changed in $50 \%$ of the sampled area, as the TRIX index and RAP, respectively. The internal area registered up eutrophic and impacted in all periods analyzed. The median area and the outer decreased their water quality, due to summer activity, while there was no change in environmental quality by RAP. A significant correlation between the indices used indicated that the RAP should be used with caution to describe the condition of water quality. This analysis has submitted be more appropriate when used in river scale as a whole, but not isolated segments.
\end{abstract}

Keywords: Eutrophication; TRIX; Rapid Assessment Protocol; Papaquara river.

\section{RESUMO}

Os corpos hídricos localizados nas zonas costeiras estão submetidos às pressões antrópicas e a perda da qualidade ambiental. O objetivo deste estudo foi avaliar a qualidade ambiental do rio Papaquara, através da qualidade da água e da paisagem ribeirinha, utilizando-se do Índice Trófico (TRIX) e do Protocolo de Avaliação Rápida (PAR). O estudo foi realizado na bacia hidrográfica localizada no norte da Ilha de Santa Catarina, Florianópolis - SC, cujo aumento populacional no veraneio é em torno de $280 \%$. O Índice Trófico e o Protocolo de Avaliação Rápida foram avaliados nos períodos de pré-veraneio, veraneio e pós-veraneio em sete pontos amostrais ao longo das áreas interna (maior adensamento populacional), mediana e externa do rio Papaquara, além de dois pontos em afluentes. O rio Papaquara mostrou-se em estado de forte estresse, sendo classificado como eutrofizado, em $77 \%$ das amostras e alterado em $50 \%$ da área amostrada, conforme os índices TRIX e PAR, respectivamente. A área interna apresentou-se eutrófica e impactada em todos os períodos analisados. A área mediana e a externa diminuíram sua qualidade da água, devido a atividade de veraneio, enquanto não houve alteração da qualidade ambiental pelo PAR. A correlação significativa entre os índices utilizados indicou que o PAR deve ser usado com cautela para descrever condição de qualidade da água. Esta análise se apresentou mais adequada quando utilizada na escala do rio como um todo, mas não por segmentos isolados.

Palavras-chave: Eutrofização; TRIX; Protocolo de Avaliação Rápida; Rio Papaquara. 


\section{INTRODUCTION}

Worldwide coastal zones cover $40 \%$ of the population who live less than $100 \mathrm{~km}$ from the seashore and those areas are under persistent demographic, economic and ecological pressure (STATHAM, 2012). The coastal river basins show high environmental vulnerability and significant anthropic interventions. Anthropic activities insert nutrients into the aquatic system from point sources (canalization, discharge of domestic and industrial effluents) and diffuse sources (fertilizers, domestic effluents and superficial outflow) which contribute to the eutrophication process and degradation of bodies of water (BRICKER; FERREIRA; SIMAS, 2003).

Eutrophication is the result of the excess of nutrients in bodies of water and it favors the increase of phytoplankton biomass and proliferation of aquatic macrophytes (CHAMBERS; PREPAS, 1994; BALDY et al., 2007). The decomposition of this biomass promotes the decrease in the dissolved oxygen concentration in aquatic environments, which results in a decrease of water quality and the reduction of aerobic organism. The eutrophication has become a global issue and it occurs in lakes, rivers and seas all over the world (RABALAIS et al., 2009). The researches involving the eutrophication of aquatic ecosystems aim at estimating the trophic state by the application of water quality and environmental index, i.e. by the development of applications methodology available to researchers and environmental managers (CUDOWSKI, 2015).

The environmental quality is not restricted only to the ecosystem because it also involves the human activity which has consequences into habitants' lives (BOTELHO; SILVA, 2004). Quality indexes for aquatic environments analyze the structure and operation of the ecosystem, based on parameters of easy perception and simplified usage. This research uses the Trophic Index (TRIX) to characterize the trophic state and the Rapid Assessment Protocol - RAP to analyze the quality of riverine environment. The measures used are examples of qualitative and quantitative indexes, respectively.

The TRIX was developed by Vollenweider et al. (1998). This index is based on the aggregation of biological (chlorophyll-a) and physicochemical variables (oxygen and nutrients) to characterize the trophic state of the system. Those parameters are important for planning and management of coastal areas because they show the biological entirety of water. This index has been applied in Brazilian and European coastal areas because it shows the current dynamics of the aquatic system (VOLLENWEIDER et al., 1998; COTOVICZ JUNIOR et al., 2012; SILVA et al., 2013; TAVARES et al., 2014).

RAP is an empiric analysis of visual-inspection, created by Plafkin et al. (1989) in the United States of America as a qualitative evaluation method which provides data about aquatic life and the quality of bodies of water, as the presence of vegetation and the diversity of habitats. In Brazil, RAP was applied for the first time by Callisto et al. (2002) in aquatic environment in Minas Gerais and Rio de Janeiro. The indicators compiled by RAP are qualifiers of the body of water or relevant phenomenon that shows and evaluate the environmental conditions (KANDZIORA; BURKHARD; MÜLLER, 2013), as the existence of riparian vegetation, solid waste and pollution point sources along the river. RAPs can be used as a way to make decisions that affect directly the environmental quality of the body of water because of the character of its ecosystem (CALLISTO et al., 2002).

The evaluation of the quality of a body of water cannot be determined only by the water quality, but actually by the physical conditions around because it allows the comprehension of its real conditions (RODRIGUES; CASTRO, 2008). The analysis of the changes in the usage and the ground cover in coastal river basins, when associated to the water analysis of limnic and marine medium, is an important tool to comprehend the changes caused by anthropic activity in different spatiotemporal levels.

The environmental stress caused by the eutrophication is potentiated during summer period because of the population increase in coastal watershed. Florianópolis, located in Brazilian Southern, is an important touristic city during summer period. The watershed is located in the North of Florianópolis and the tourism causes the increase of the population in that area. Despite the natural attraction of its beaches, the treatment of domestic effluents is still incipient because only $46 \%$ of those effluents are treated in Wastewater Treatment Plant (WTP) and the remnant part is thrown into bodies of water (TRATA BRASIL, 2008). Considering this situation, this research aimed at analyzing the effects of population increase during summer period into the Papaquara river and the results of this pressure into the area and in the trophic state in the body of water, which is a coastal watershed. To do so, the environmental quality indexes TRIX and RAP were applied and these qualitative and quantitative tools can support the environmental management in a simple and available way.

\section{MATERIALS AND METHODS}

\section{Study area}

The Papaquara river watershed is located in the subtropical region $\left(27^{\circ} 26^{\prime} 31,03^{\prime \prime}\right.$ and $27^{\circ} 28^{\prime} 6,43^{\prime \prime} \mathrm{S}$; 48 $25^{\circ}$ '4,42 e $48^{\circ} 29^{\prime} 58,77^{\prime \prime} \mathrm{W}$ ) in the North of the island, in Florianópolis city - SC (Figure 1).

There are 30.899 habitants living in the Papaquara river watershed, which is an area required by the tourism during summer period, and in this time of the year the population increases about 280\% (CAMPANÁRIO, 2007; IBGE, 2010). The internal area of the river receives effluents treated through a secondary way, arising from WTP of Canasvieiras, through an artificial sluice that flows $3.600 \mathrm{~m}^{3} /$ day. The highest urban density of the island is located in this area, and the density decreases toward the river mouth and ends in the beginning of Carijós Ecological Station.

There is remaining flora from Atlantic Forest in the watershed area and it is composed by vegetation in initial stages of regeneration (capoeirinha and capoeira) arboreal sandbanks and mangrove, and the latter is protected by Carijós Ecological Station. However, the biggest part of the riparian vegetation was suppressed by straightening, pasture and landfills because of real estate speculation (PORTO FILHO et al., 2012). The Papaquara river watershed is located in an important area of protection and reproduction of endangered species, as Neotropical otter (Lontra longicaudis) and broad-snouted caiman (Caiman latirostris) (CERTI, 2010). 

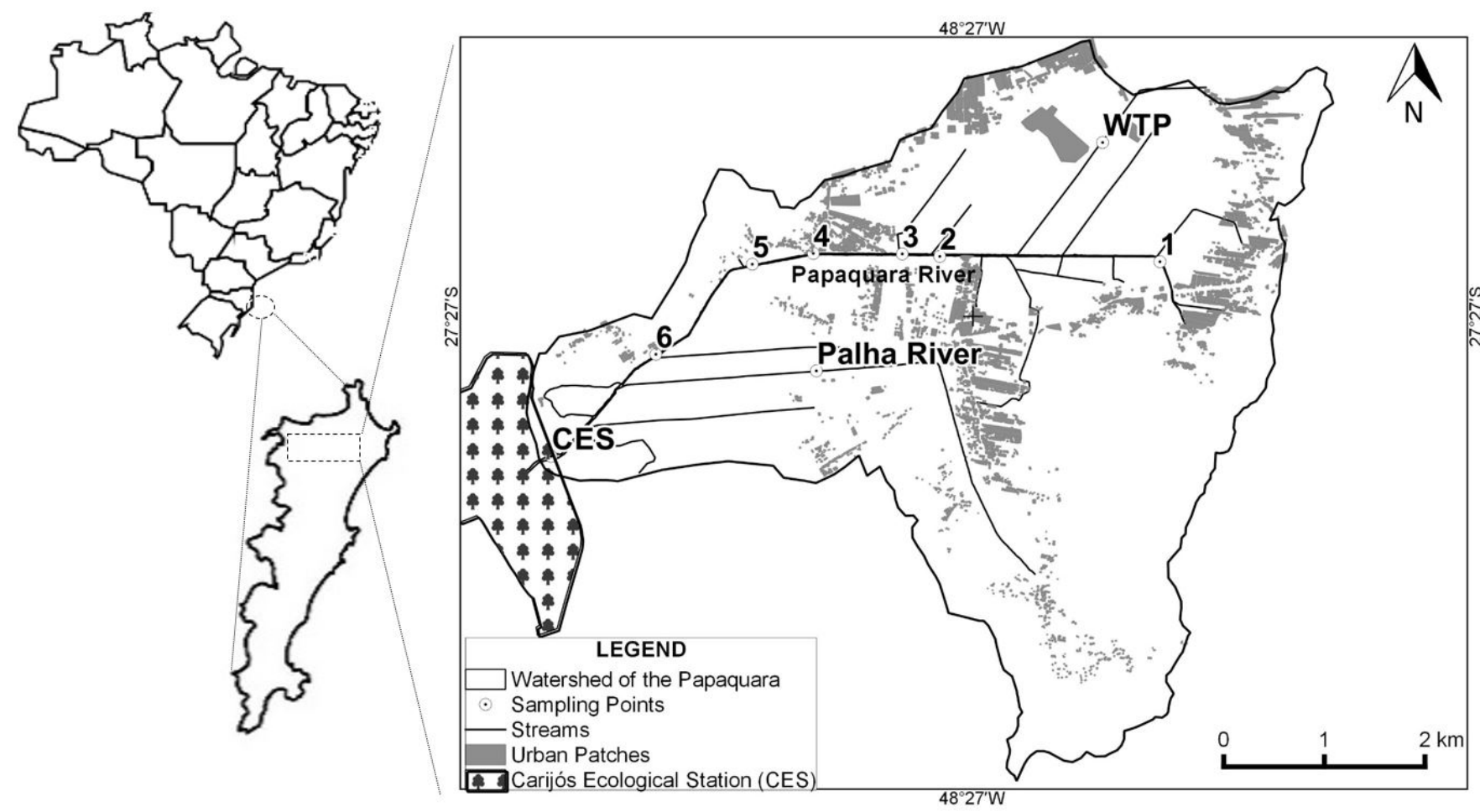

Figure 1. The map of the watershed of the Papaquara river showing the sampling points in the internal (1 and 2), median (3 and 4$)$ and external areas (5 and 6), points in the WTP channel, the Palha river, Carijós Ecological Station (CES) and the urban patches (in gray). Source: Fidélis Filho (1998). Adapted.

\section{Sampling}

The areas were determined according to the urban density in the watershed and three areas were considered along the Papaquara river: the internal area (sample points 1 and 2), median area (sample points 3 and 4) and external area (sample points 5 and 6). A sampling point was defined in the Palha river (P), in the Canasvieiras WTP channel, affluents of the Papaquara river which is a possible sources of nutrients, and in the river mouth in Carijós Ecological Station were analyzed (Figure 1). Considering that summer period begins by the end of December and finishes in mid-February, the effect of this period was investigated during three sampling periods. Each period was sampled in three different periods: pre-summer (PS) from October to December/2013; summer period (S) between January and February/2014 and post-summer (SP), between March and April/2014, which results in 9 sampling and 81 samples.

\section{Water quality analysis and TRIX}

The samples were collected at low syzygy tide, when inland waters had the most significant performance in the system. The surface water was obtained using plastic bottles which were previously cleaned in the laboratory and fixed to a $100 \mathrm{~cm}$ ( $\sim 0$ inches) clipping stick. In areas underneath bridges, the water samples were obtained using a Van Dorn-type plastic water sampler of horizontal closure. The samples were preserved in thermal boxes with ice and protected from the sunlight until the processing in the lab.

The salinity level on water was measured in situ using a thermosalinometer (YSI EC 300). The concentration of dissolved oxygen was evaluated by Winkler method and the water obtained, in situ fixation, preservation, analysis and calculus were developed according to Strickland and Parsons (1972). In this work we applied the Apparent Oxygen Utilization (AOU) that provides the evaluation of consumed oxygen concentration in the water column, considering the presumable difference of saturation from the sample and the in situ measure (VOLLENWEIDER et al., 1998). In the laboratory, the water samples were filtered according to the procedures described by Strickland and Parsons (1972), using microfiber filter of $47 \mathrm{~mm}$ GF-5. After the filtration, the samples were frozen at $-20{ }^{\circ} \mathrm{C}$.

Dissolved inorganic nitrogen (DIN) is the sum of ammoniacal nitrogen $\left(\mathrm{NH}_{4}\right)$, nitrate $\left(\mathrm{NO}_{3}\right)$ and nitrite $\left(\mathrm{NO}_{2}\right)$ and they are evaluated by colorimetric methods, usual for salt water and brackish water. The total concentration of ammoniacal nitrogen was quantified by the indophenol blue colorimetric method, method application range from 0.7 to $560 \mu \mathrm{g} . \mathrm{L}^{-1}$ (GRASSHOFF et al., 1983). The oxidized inorganic forms of nitrogen (nitrite and nitrate) were quantified simultaneously. The nitrate was reduced to nitrite through the amalgam cadmium/copper (GRASSHOFF et al., 1983). The nitrite was quantified by the colorimetric technique based on Griess reaction with sulfanilamide and dihydrochloride with method application range from 0.14 to $280 \mu \mathrm{g} / \mathrm{L}^{-1}$ (GRASSHOFF et al., 1983). The orthophosphate, dissolved inorganic phosphorus (DIP), 
was quantified by molybdenum-blue colorimetric method, method application range from 0.3 to $870 \mu \mathrm{g} \cdot \mathrm{L}^{-1}$ (GRASSHOFF et al., 1983). The samples which concentration exceeded the method limit were diluted appropriately and the concentrations were corrected by the dilution factor used. The absorbances were read in a double beam spectrophotometer Hitachi UV-290, from calibration with solutions certified by Merck ${ }^{\circledR}$ (GRASSHOFF et al., 1983). The phytoplankton biomass (chlorophyll-a) was quantified by fluorimetry (Turner Designer-Trilogy Fluorometer) (STRICKLAND; PARSONS, 1972).

\section{Trophic index - TRIX}

The Trophic Index (TRIX) classifies the trophic state of coastal areas in ultraoligotrophic (<2), oligotrophic (2-4), mesotrophic (4-5), mesotrophic to eutrophic (5-6), and eutrophic (6-8) (COTOVICZ JUNIOR et al., 2012). The data of superficial water analysis was applied to Equation 1, described in Vollenweider et al., (1998), to stimulate the trophic state of each sample point:

$$
T R I X=(\log 10[\text { Chl } x \text { AOU } x \text { DIN } x \text { DIP }]+k) / m
$$

In this equation, $\mathrm{Chl}$ is the concentration of chlorophyll- $a$ $\left(\mu \mathrm{g} . \mathrm{L}^{-1}\right)$; AOU is the apparent utilization of oxygen or the deviation of the concentration of dissolved oxygen measured in the sample in relation to the saturation value; DIN is the concentration of dissolved inorganic nitrogen $\left(\mu \mathrm{g} . \mathrm{L}^{-1}\right)$; DIP is the concentration of dissolved inorganic phosphorus $\left(\mu \mathrm{g} \cdot \mathrm{L}^{-1}\right)$; the $k$ coefficient is the sum of the minimum limits of the variables and $m$ is the log range of the variables.

\section{Rapid Assessment Protocol - RAP}

The Rapid Assessment Protocol (RAP) was applied in each day of collection in each sample point. The RAP used was modified considering the protocols applied by Hannaford et al. (1997), Callisto et al. (2002), Looy et al. (2006), Rodrigues and Castro (2008) and Brinson et al. (2013), in order to adapt the variables to the characteristics of the study field (Table 1).

The RAP modified in this research characterized the environmental quality of the riverine scenery by the urbanized area, by the presence of aquatic vegetation, of riparian vegetation and solid waste in the riverside and by the change in the morphology

Table 1. The Rapid Assessment Protocol applied in the watershed of the Papaquara river.

\begin{tabular}{|c|c|c|c|}
\hline LEGEND & 5 Points & 2,5 Points & 0 Points \\
\hline 1. Presence of riparian vegetation & $\begin{array}{l}\text { Above } 90 \% \text { of the riparian } \\
\text { vegetation }\end{array}$ & $\begin{array}{l}\text { Between } 50 \text { and } 70 \% \text { of the native } \\
\text { vegetation and deforestation }\end{array}$ & $\begin{array}{l}\text { Less than } 50 \% \text { of the native } \\
\text { riparian vegetation }\end{array}$ \\
\hline $\begin{array}{l}\text { 2. Extension of the riparian } \\
\text { vegetation }\end{array}$ & $\begin{array}{l}\text { Longer than } 18 \mathrm{~m} \text { (no anthropic } \\
\text { activity) }\end{array}$ & $\begin{array}{l}\text { Between } 6 \text { and } 12 \mathrm{~m} \\
\text { (with anthropic activity) }\end{array}$ & $\begin{array}{l}\text { Shorter than } 6 \mathrm{~m} \\
\text { (restricted vegetation) }\end{array}$ \\
\hline 3. Surrounding vegetation & Well preserved native species & $\begin{array}{l}\text { Vegetation formed by native } \\
\text { species and scarcity of exotic } \\
\text { vegetation }\end{array}$ & $\begin{array}{l}\text { Vegetation constituted by exotic } \\
\text { species and scarcity of native } \\
\text { vegetation }\end{array}$ \\
\hline $\begin{array}{l}\text { 4. Types of occupation of the } \\
\text { riversides in the bodies of water } \\
\text { (main activity) }\end{array}$ & Natural vegetation & $\begin{array}{l}\text { Grazing field/ agriculture/ } \\
\text { monoculture/ reforestation }\end{array}$ & $\begin{array}{l}\text { Residential/Commercial/ } \\
\text { Industrial }\end{array}$ \\
\hline 5. Types of bottom & Sand/Mud & $\begin{array}{l}\text { Sand/Solid waste (trash, building } \\
\text { material, etc.) }\end{array}$ & Cement/Ducted \\
\hline $\begin{array}{l}\text { 6. Erosion close to/or of the } \\
\text { riversides and siltation of the river }\end{array}$ & Absent & Moderate & Intense \\
\hline 7. Transparency of the water & Transparent & Turbid & Opaque or Colored \\
\hline 8. Sinuosity of the channel & Existence of curves & Monotonous habitat, less sinuous & Plumbing/Straight Channel \\
\hline 9. Changes in the river channel & Non-ducted & 40 to $80 \%$ of the river modified & $\begin{array}{l}\text { Riversides modified more than } \\
80 \%\end{array}$ \\
\hline $\begin{array}{l}\text { 10. Other anthropic changes of } \\
\text { the riversides }\end{array}$ & Absent & $\begin{array}{l}\text { Changes caused by domestic } \\
\text { interference (sewer, trash, etc.) }\end{array}$ & $\begin{array}{l}\text { Changes caused by Industrial/ } \\
\text { urban interference (factories, } \\
\text { plumbing, straighten of the hydric } \\
\text { course) }\end{array}$ \\
\hline $\begin{array}{l}\text { 11. Point sources of visible } \\
\text { pollution }\end{array}$ & Absent & Moderate & Intense \\
\hline 12. Eviction of solid waste & Absent & Moderate & Intense \\
\hline $\begin{array}{l}\text { 13. Urbanization nearby the water } \\
\text { course }\end{array}$ & Absent & Moderate & Intense \\
\hline $\begin{array}{l}\text { 14. Presence of opportunistic } \\
\text { aquatic vegetation in the riverbed }\end{array}$ & $\begin{array}{l}\text { Absence of aquatic vegetation in } \\
\text { the riverbed }\end{array}$ & $\begin{array}{l}\text { Small amount of aquatic } \\
\text { vegetation }\end{array}$ & $\begin{array}{l}\text { Considerable amount of aquatic } \\
\text { vegetation }\end{array}$ \\
\hline $\begin{array}{l}\text { 15. Presence of native fauna } \\
\text { (fishes, reptiles, mammals, etc.) }\end{array}$ & Visible presence of fauna & Distinct presence of fauna & Non-existence of fauna \\
\hline
\end{tabular}

Source: Callisto et al. (2002). Adapted. 
of the river, and more variables. These descriptors are important for the management of the environmental quality in coastal watersheds (KANDZIORA; BURKHARD; MÜLLER, 2013).

The final values of the RAP were obtained from the sum of the values attributed to each parameter, according to the conditions found in the sample point on the collection day: impacted area ( $<25$ points), altered area $(>25$ points) and natural area ( $>50$ points).

\section{Data processing}

The permutational multivariate analysis of variance, PERMANOVA, was applied to the results of TRIX and RAP indexes to test if there was a significant difference between the areas and the sample periods. The analysis was constituted based on Euclidean distance matrix, generated with normalized data and applying 999 permutations (ANDERSON, 2001).

The principal coordinates analysis (PCoA) was used to visualize the square matrix, describing the similarity or dissimilarities between variables and areas and the sample periods (LANDIM, 2011). The PCoA was applied with Spearman Rank Correlation Coefficient $\mathrm{p}>0.05$, using PRIMER software $6^{\circledR}$. The analysis of simple correlation was elaborated to investigate the correlation between the indexes generated by TRIX and RAP, with the help of R software, version 3.1.2 (R CORE TEAM, 2015).

The urbanization patches and aquatic vegetation in the riverbed (macrophytes) were determined with the help of Quantum software GIS 2.8.2 (QGIS DEVELOPMENT TEAM, 2015), considering the orthoimages of the study area (IPUF, 2012).

\section{RESULTS AND DISCUSSIONS}

\section{Urbanization in the of the Papaquara river watershed}

The urban patches in the Papaquara river watershed represented $22 \%$ of the total area, which is $32 \mathrm{~km}^{2}$. Consonant to Arnold Junior and Gibbons (1996), the watershed may be considered impacted, when the urbanization occupies from 10 to $30 \%$ of its area. In the Papaquara river watershed, the median area covers $15 \mathrm{~km}^{2}(47 \%)$, the internal area covers $12 \mathrm{~km}^{2}(37 \%)$ and the external area, $5 \mathrm{~km}^{2}(16 \%)$. The internal area showed the biggest patch of relative urbanization: $51 \%$ of that stretch was waterproofed because of this occupation; in the median and external areas the percentages were $8 \%$ and $2 \%$ respectively. Because of the urbanization projects in progress and foreseen in short term, the internal area of the Papaquara river will increase from $51 \%$ to $87 \%$. The urban watersheds suffer imbalance because of the anthropic occupations and the missing of appropriate basic sanitation, which makes it more difficult to recycling and nutrient removal (BREGUNCE et al., 2011).

The domestic wastewater treatment in the watershed area covers $39 \%$ of the residences and the rest is connected clandestinely to the rainwater drainage system or use cesspools and sinkholes and this affects the shallow water table. The temporary population of summer period triples the number of residents in the watershed area and it increases the consumption of potable water, which may overload the Wastewater Treatment Plant (WTP), which efficiency in total phosphorus removal is 30\% (FATMA, 2009). On the other hand, the temporary population is responsible for the increase of local economy, and the revenue generated by summer period tourism in Santa Catarina was approximately 3 billion reais from march to january, 2013, and Florianópolis city was in second place in the national rank, with $18 \%$ of the international reception (BRASIL, 2013; FIESC, 2014).

\section{Physicochemical characteristics and concentration of nutrient in the Papaquara river watershed}

The Papaquara river is located in a microtidal area, but, even in low tide, the salinity above 0.5 psu was found all over the sample points through the river. The values above 20 psu were identified in the outermost points of the river, and the maximum value of 32 psu was found in the second sample of summer period, during the flood current (Table 2).

The lowest salinity levels were found in the Wastewater Treatment Plant (WTP) channel $(0.4 \pm 0.1 \mathrm{psu})$ and in the Palha river $(0.1 \pm 0.0 \mathrm{psu})$, which are affluents of the Papaquara river, and those values were observed during all the sampling periods (Table 3). In summer period, the salinity was, on average, higher in all sampling areas, varying from $1.4 \pm 2.2 \mathrm{psu}$ in the internal area to $20.9 \pm 11.8$ psu in Ecological Station. The salinity in each sampling area was similar in pre-summer and after-summer periods. The dilution of internal waters by the incoming tide is important for the maintenance of water quality that receives discharge of effluents (ARAÚJO; MELO, 2000). This condition was higher during summer period, indicated by the higher salinity level.

Although the most evident effect in marine water had occurred during summer period, the highest percentage of Apparent Oxygen Utilization (AOU) occurred in this period, from the WTP channel $(97.2 \pm 4.9 \%)$ until the median area $(87.5 \pm 11.8 \%)$ and in the Palha river $(80.9 \pm 29.9 \%)$. Only in the external area and in the Carijós Ecological Station, the AOU percentage was lower in summer period in relation to the other periods (Table 3). 88,9\% of the samples from the Papaquara river were in hypoxia during this

Table 2. Variation of the height of the astronomical tide expected and the salinity between the sample periods. Minimum and maximum salinity values along the river, internal area (I) and sample point of Carijós Ecological Station (CES).

\begin{tabular}{cccl}
\hline Period & Date & Tide $(\mathbf{T})$ & \multicolumn{1}{c}{ Salinity $(\mathrm{psu})$} \\
\hline \multirow{3}{*}{ PS } & $10 / 23 / 13$ & $0.4-0.7$ & $0.5(\mathrm{I})-20.2(\mathrm{CES})$ \\
& $11 / 07 / 13$ & $0.5-0.9$ & $0.4(\mathrm{I})-17.5(\mathrm{CES})$ \\
& $12 / 06 / 13$ & $0.6-0.9$ & $0.3(\mathrm{I})-15(\mathrm{CES})$ \\
\hline \multirow{3}{*}{$\mathrm{S}$} & $01 / 22 / 14$ & $1-0.5$ & $0.4(\mathrm{I})-8.4(\mathrm{CES})$ \\
& $02 / 14 / 14$ & $0.3-1.2$ & $0.9(\mathrm{I})-29.8(\mathrm{CES})$ \\
& $02 / 18 / 14$ & 0.3 & $0.3(\mathrm{I})-22.5(\mathrm{CES})$ \\
\hline \multirow{3}{*}{$\mathrm{SP}$} & $03 / 30 / 14$ & $0.2-0.5$ & $0.4(\mathrm{I})-21(\mathrm{CES})$ \\
& $04 / 16 / 14$ & $0.2-0.3$ & $0.9(\mathrm{I})-18.2(\mathrm{CES})$ \\
& $04 / 29 / 14$ & 0.3 & $0.5(\mathrm{I})-11.8(\mathrm{CES})$ \\
\hline
\end{tabular}

Source: DHN (2014) and research in loco. 
Table 3. Data used in TRIX (Trophic Index), dissolved inorganic nitrogen (DIN), dissolved inorganic phosphorus (DIP), chlorophyll- $a$ (Chl-a), apparent oxygen utilization (AOU). Internal area (I), median area (M), the Palha river (P), external area (E) and Carijós Ecological Station (CES). In the pre-summer (PS), summer (S) and pos-summer (SP) periods.

\begin{tabular}{|c|c|c|c|c|c|}
\hline Area & Períod & AOU (\%) & DIN $\left(\mu \mathrm{g} . \mathrm{L}^{-1}\right)$ & DIP $\left(\mu g \cdot \mathrm{L}^{-1}\right)$ & Chl-a ( $\mu$ g. $\left.L^{-1}\right)$ \\
\hline \multirow{3}{*}{ WTP } & PS & $89.1 \pm 10.3$ & $2.098 .6 \pm 167.8$ & $1.728 \pm 1.367 .7$ & $0.5 \pm 0.6$ \\
\hline & S & $97.2 \pm 4.9$ & $2.467 .1 \pm 851.0$ & $4.213 .4 \pm 631$ & $0.1 \pm 0.0$ \\
\hline & SP & $95.6 \pm 7.7$ & $2.966 .0 \pm 530.8$ & $2.503 .2 \pm 1.204 .0$ & $0.1 \pm 0.0$ \\
\hline \multirow{3}{*}{ I } & PS & $92.3 \pm 6.3$ & $1.861 .7 \pm 183.5$ & $247.7 \pm 243.0$ & $0.3 \pm 0.4$ \\
\hline & $\mathrm{S}$ & $93.3 \pm 7.1$ & $1.843 .7 \pm 2.055$ & $431.8 \pm 293.7$ & $0.9 \pm 0.7$ \\
\hline & SP & $91.2 \pm 11.3$ & $2.055 .1 \pm 242.6$ & $300.3 \pm 271.8$ & $0.3 \pm 0.2$ \\
\hline \multirow{3}{*}{ M } & PS & $85.0 \pm 3.1$ & $1.215 .2 \pm 266.1$ & $130.0 \pm 87.8$ & $0.2 \pm 0.1$ \\
\hline & $\mathrm{S}$ & $87.5 \pm 11.8$ & $1.460 .4 \pm 193.8$ & $128.1 \pm 62.1$ & $0.9 \pm 0.8$ \\
\hline & SP & $86.3 \pm 10.1$ & $1.652 .6 \pm 187.5$ & $286.6 \pm 176.7$ & $0.2 \pm 0.2$ \\
\hline \multirow{3}{*}{$\mathrm{P}$} & PS & $61.3 \pm 13.4$ & $1.035 .1 \pm 549.0$ & $17.7 \pm 7.7$ & $0.1 \pm 0.0$ \\
\hline & $\mathrm{S}$ & $80.9 \pm 29.9$ & $1.241 .5 \pm 442.1$ & $31.3 \pm 15.1$ & $0.2 \pm 0.0$ \\
\hline & SP & $56.0 \pm 18.0$ & $1.606 .4 \pm 589.2$ & $30.0 \pm 17.3$ & $0.1 \pm 0.1$ \\
\hline \multirow{3}{*}{$\mathrm{E}$} & PS & $76.3 \pm 5.7$ & $959.2 \pm 237.4$ & $54.0 \pm 35.8$ & $0.1 \pm 0.2$ \\
\hline & S & $63.6 \pm 24.1$ & $911.4 \pm 378.2$ & $132.7 \pm 142.9$ & $1.0 \pm 0.7$ \\
\hline & SP & $75.5 \pm 16.5$ & $1.550 .0 \pm 356.5$ & $248.9 \pm 115.5$ & $0.3 \pm 0.1$ \\
\hline \multirow{3}{*}{ CES } & PS & $42.8 \pm 7.8$ & $506.9 \pm 28.1$ & $25.3 \pm 15.6$ & $0.1 \pm 0.1$ \\
\hline & $\mathrm{S}$ & $28.8 \pm 15.5$ & $550.5 \pm 99.3$ & $38.7 \pm 21.3$ & $0.9 \pm 0.8$ \\
\hline & SP & $20.0 \pm 21.0$ & $584.3 \pm 153.4$ & $217.4 \pm 154.7$ & $0.5 \pm 0.3$ \\
\hline
\end{tabular}

Source: Authors.

research. The waters that presented $<30 \%$ of oxygen saturation or $>70 \%$ of $\mathrm{AOU}$ indicate that the aquatic environment may suffer modifications as: decrease the extension of the habitats, mortality of the organisms, decrease of the biodiversity, change in the trophic structure and modify in the functions and services of the ecosystem (VILLATE et al., 2013). The low oxygen saturation may occur as a result of the excess of organic matter, from domestic wastewater or generated by the eutrophication, associated to the low hydrodynamics and renovation of the water (BRICKER; FERREIRA; SIMAS, 2003).

The water bodies that receive residual water from domestic effluents show high concentration of P (WITHERS; JARVIE, 2008). The DIP concentrations were at least one order of magnitude higher in WTP channel and the maximum was 4.213.4 $\pm 631 \mu \mathrm{g} . \mathrm{L}^{-1}$ during summer period, when compared to other sampling points, during all the periods. The lowest values occurred in the Palha river, where the minimum was $17.7 \pm 7.7 \mu \mathrm{g} . \mathrm{L}^{-1}$ in pre-summer (Table 3). This result corroborates that the population increase during summer period overloads the WTP Canasvieiras, which affects its efficiency in phosphorus removal. Considering that the biggest influence of marine water occurred in summer period, along the Papaquara river, it reinforces that the population increase caused the modification in water quality, which already is impaired because of the pressure from annual residents.

The DIN concentration increased along the river, and the minimum concentrations occurred in Ecological Station water $\left(506.9 \pm 28.1 \mu \mathrm{g} . \mathrm{L}^{-1}\right)$ during pre-summer. The DIN concentration above $1.500 \mu \mathrm{g} . \mathrm{L}^{-1}$ occurred in $50 \%$ of the samples in the Papaquara river. Smith, Tilman and Nekola (1999) pointed out that eutrophic environments show concentrations of TN and TP higher than $1.500 \mu \mathrm{g} . \mathrm{L}^{-1}$ and $75 \mu \mathrm{g} . \mathrm{L}^{-1}$, respectively. In the Papaquara river, those concentrations were observed in the organic fraction of TN and TP, which is the most bioavailable fraction.

\section{Biomass (chlorophyll- $a$ and aquatic macrophytes) in the Papaquara river}

Despite the high concentrations of DIN and PID nutrients along the Papaquara river, the concentrations of phytoplankton chlorophyll- $a$ were low when compared to the concentrations of $2.7 \mu \mathrm{g} . \mathrm{L}^{-1}$ found in the North Bay of Santa Catarina, SC (SIMONASSI et al., 2010) and the concentrations of $15 \mu \mathrm{g} \cdot \mathrm{L}^{-1}$ observed in Garatuba Bay, PR (MIZERKOWSKI et al., 2012). In the Papaquara river, the highest concentrations of chlorophyll- $a$ occurred during summer period in all the areas, internal $\left(0.9 \pm 0.7 \mu \mathrm{g} . \mathrm{L}^{-1}\right)$, median $\left(0.9 \pm 0.8 \mu \mathrm{g} . \mathrm{L}^{-1}\right)$ and external $\left(1.0 \pm 0.7 \mu \mathrm{g} . \mathrm{L}^{-1}\right)$. On the other hand, it was observed the increase of aquatic macrophytes covering the layer of water, in the internal and median areas of the Papaquara river, during and after summer. The superficial water that receives high loads of $\mathrm{N}$ and $\mathrm{P}$ from domestic effluents, stimulate the growth of aquatic vegetation, which challenges with the phytoplankton for resources, as sunlight, which is not limiting the growth of macrophytes that grow in the surface of the water (CLOERN, 2001; BIANCHINI JUNIOR, 2003).

The presence of aquatic macrophytes in the internal and median areas of the Papaquara river, as the Salvinia auriculata (ear's mouse lettuce), Pistia stratiotes (water lettuce) and Eichhornia crassipes (water hyacinth) was favored by the entrance of nutrients, light incidence, lack of herbivorous predators and anthropic changes, as drainages and straightening of the water channel (MUFARREGE; HADAD; MAINE, 2010). In the internal area, it was observed that $51 \%$ of the layer of water of the Papaquara river has been lined by aquatic macrophytes, $26 \%$ in the median area and the external area didn't present this vegetation, when analyzed through the orthoimage (IPUF, 2012). The aquatic macrophytes filter the nutrients of the water column, according to the research developed in the river Mogi-Guaçu, where was found that $71 \%$ of the 
nitrogen was tied in the biomass of the macrophytes and $29 \%$ was available in the water column (NOGUEIRA; ESTEVES, 1990). The macrophytes are largely used in wetland systems of domestic effluent treatment, because of its efficiency in the absorption of phosphorus and heavy metals (MUFARREGE; HADAD; MAINE, 2010). However, if they were kept in the system, the macrophytes would offer these nutrients to the environment again when they die, which increases the eutrophication process and favors the oxygen consumption (BIANCHINI JUNIOR, 2003), according to the results of this study.

\section{Trophic state of the Papaquara river and affluents (Trophic index - TRIX)}

The Papaquara river and affluents had $77 \%$ of the samples in eutrophication state. The WTP channel, the internal and median areas of the river and the affluent of the Palha river were in eutrophic state during all the periods investigated, with the TRIX above 6.0 (Figure 2). The external area was classified as: mesotrophic to eutrophic in pre-summer (5.2 \pm 1.7$)$, and eutrophic in summer period (6.7 \pm 0.6$)$ and post-summer (7.1 \pm 0.4$)$. The Carijós Ecological Station point was classified as oligotrophic (2.0 \pm 1.8$)$ in pre-summer, becoming mesotrophic in summer period (5.7 \pm 0.7$)$ and mesotrophic to eutrophic in post-summer (5.8 \pm 1.1$)$.

In the Carijós Ecological Station point the eutrophic state was observed in $21 \%$ of the 48 measures done in the Papaquara river, between 2005 and 2006 (SILVA et al., 2013). In the research developed in the estuary of the river Potengi (RN), applying the TRIX, the influence of the superficial outflow of the drainage basin, the sum was an important coefficient for the water quality (TAVARES et al., 2014). The urbanization, the salinity and the TRIX along the Papaquara river watershed pointed out that the internal and median areas were more vulnerable to the entrance of the nutrients via domestic effluent and via WTP, which causes the degradation of the water quality. In addition, this effect spread to areas further than the point and diffuse sources, reaching the external area and the Ecological Station. It is important to maintain the monitoring of the water quality of the Papaquara river to comprehend the effects of the anthropic (i.e. entrance of nutrients by the urbanization) and natural agents (dilution of the waters by the sea) are affecting the system and the surrounding area, including the area of environmental protection.

\section{Environmental quality of the watershed of the Papaquara river}

The application of the RAP along the Papaquara river pointed out that $50 \%$ of the sampling areas had changed ( $>25$ points) and $16 \%$ were impacted $(<25$ points). As observed by the TRIX, the most significant changes were registered in WTP channel, which was impacted in all the sampling periods (Figure 2). The internal area was impacted in all the periods analyzed. The medium area and the Palha river were classified as changed in all the sampling periods, while the external area and the sample point from the Carijós Ecological Station were classified as naturals $(>50)$ in this study.

The Papaquara river showed high environmental stress level, according to TRIX and RAP, and more than $50 \%$ of the areas were eutrophic and modified. Vargas and Ferreira Júnior (2012) applied the RAP index, proposed by Callisto et al. (2002), in two watersheds in the state of Espírito Santo, where they observed that the areas that suffered high changes caused by the usage and occupation of the soil, suffered loss of environmental quality, without significant changes in the water quality. In this study we observed the opposite, the external area and sampling point of Ecological Station presented natural conditions according to RAP, but the water showed signals of eutrophication in the period of higher population pressure, during summer and in post-summer (Figure 2).

Considering the orthoimages from 2012 (IPUF, 2012) and research in loco, it was found $37 \%$ of riparian vegetation which was composed by secondary vegetation and exotic vegetation (Pinus sp.). The median area showed $68 \%$ of the riparian vegetation, and the rest of this area was suppressed by irregular occupations
A

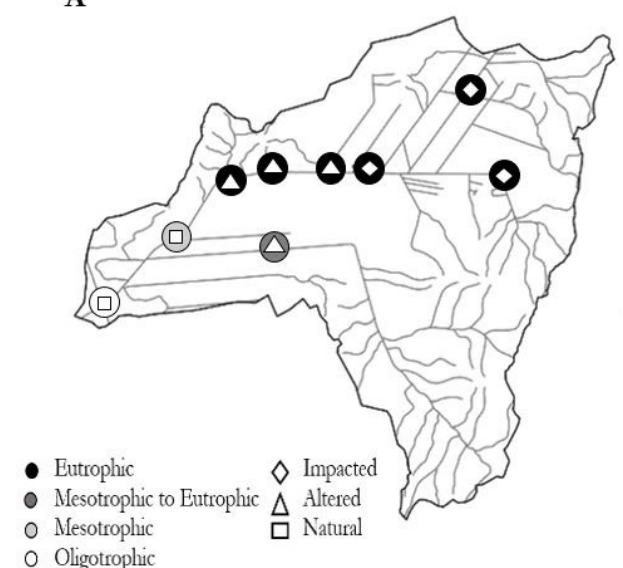

B

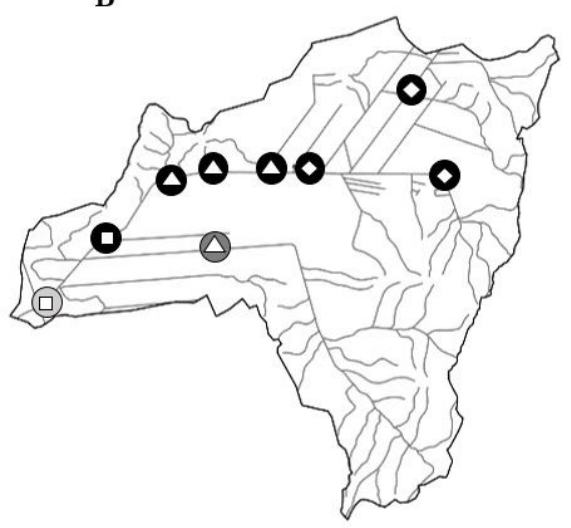

C

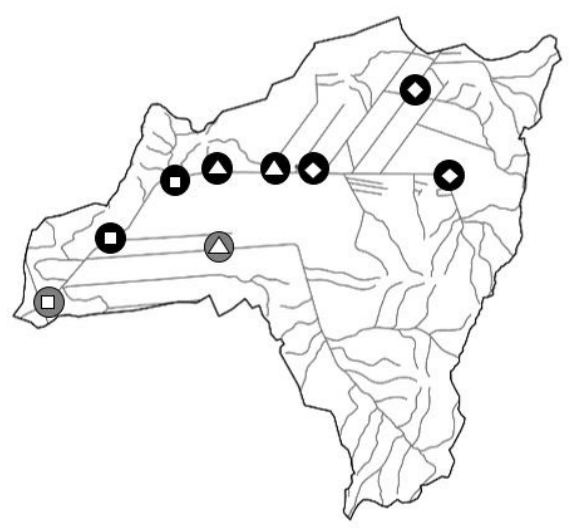

Figure 2. Simplified representation of TRIX (eutrophic, mesotrophic to eutrophic, mesotrophic and oligotrophic) and of RAP (impacted, changed and natural) in the sampling periods, pre-summer (A), summer (B) and post-summer (C). Source: Authors. 
and pasture. In the external area, it was observed that $71 \%$ of the riparian vegetation was composed by mangroves and saltmarshes. The riparian vegetation and the wet areas are environmental quality indicators in RAP, because they are landscape components and they contribute to the cycle and retention of $\mathrm{P}$ and $\mathrm{N}$, as observed in ecosystems of other countries, as the United States of America, Canada and Europe (RANALLI; MACALADY, 2010). The mangrove and the saltmarshes are considered "chemical reactors" because of their physiologies, the biogeochemical processes and the active influences in the nutrients mobility (SILVA et al., 2007). This vegetal covering prevents the erosion of the riversides, the silting of the riverbed, the habitat loss and flooding in riverine areas (MINATTI-FERREIRA; BEAUMORD, 2006).

The Papaquara river has a very low declination, i.e., from 2 to $6 \%$, which slows the layer outflow of the water (SOCIOAMBIENTAL, 2004). The marginal inclinations were exposed because of the suppression of the riparian vegetation. The river had several straightening areas that contributes to the leaching of the sediments, which are carried to the riverbed and accelerates the silting process. Those conditions favor a longer period of the water into the system and it weakens the system to the entrance of nutrients and pollutants (NEAL et al., 2008).

Despite the Brazilian environmental law for the protection of Permanent Preservation Areas (PPA), in the Papaquara river they have been replaced by exotic species (Pinus), pasture and urbanization. The suppression of the riparian vegetation, including the mangroves, reduce the quality of coastal water and changes the ecosystem services, including fish and crustaceans (LI et al., 2014).

\section{Integration Index TRIX and RAP in the analysis of the environmental quality}

The variable analyzed by RAP offered by a simplified vision by the environmental quality of the riparian landscape. This characteristic of the RAP that provides a qualitative analysis allowed a good correlation with the TRIX, which uses quantitative values. The TRIX by the water analysis pointed out that $77 \%$ of the samples of the Papaquara river showed eutrophic state and the RAP characterized that $49 \%$ of those sampling points were modified and $16 \%$ were impacted. The correlation between the TRIX and RAP indexes, when analyzed amongst all the sampling periods, was significant (Pearson's method, r: -0.50, p: 0.00, $\mathrm{df}_{1.79}$ : 26.02). The reverse correlation was associated to the fact that the highest value of the TRIX and the lowest RAP indicate the lowest environmental quality. In the correlation of those parameters by sampling period, only in pre-summer ( $\mathrm{r}:-0.66, \mathrm{p}: 0.00, \mathrm{df}_{1.25}$ : 19.74) and summer period ( $\left.\mathrm{r}:-.057, \mathrm{p}: 0.00, \mathrm{df}_{1.25}: 12.24\right)$ these indexes were significantly correlated. However, in the analysis of the area and with all the data of the sampling periods, only in the internal area the TRIX and the RAP were correlated ( $\mathrm{r}:-0.47$, p: $\left.0.01, \mathrm{df}_{1.25}: 6.98\right)$.

The multivariate analysis of the PERMANOVA pointed out that the internal area remained with the same quality in all the sampling periods (eutrophic and impacted). The median area showed the same quality (eutrophic and modified) in summer and post-summer periods (P: 0.85, p:0.40, $\mathrm{df}_{1.10}: 10$ ), differing from pre-period (p: 0.02 and p:0.04, respectively). While the quality of the external area was modified during all the sampling periods, which was the biggest difference between pre-summer and postsummer periods (P: 2.66, p: 0.01, $\left.\mathrm{df}_{1.10}: 10\right)$. The analysis was also developed amongst the sampling periods; in pre-summer all the areas were characterized as different (p: 0.001). While the internal and median areas were similar in summer (P: 1.59, p: 0.12, $\left.\mathrm{df}_{1.10}: 11\right)$ and post-summer (P: 1.53, p: 0.12, $\left.\mathrm{df}_{1.10}: 9\right)$, and both were different in the external area (p: 0.01).

The $\mathrm{PC}_{\mathrm{O}} \mathrm{A}$ showed the main spatial and temporal tendencies observed in this study for the TRIX data (and its descriptors) and RAP (Figure 3). The $\mathrm{PC}_{\mathrm{O}} 1(45.2 \%)$ and $\mathrm{PC}_{\mathrm{O}} 2$ (27.2\%) axes represented $72.4 \%$ of the data variability. The axis 1 pointed out a spatial tendency, i.e., samples of the external areas are placed in the positive portion of the axis, in opposition to the samples

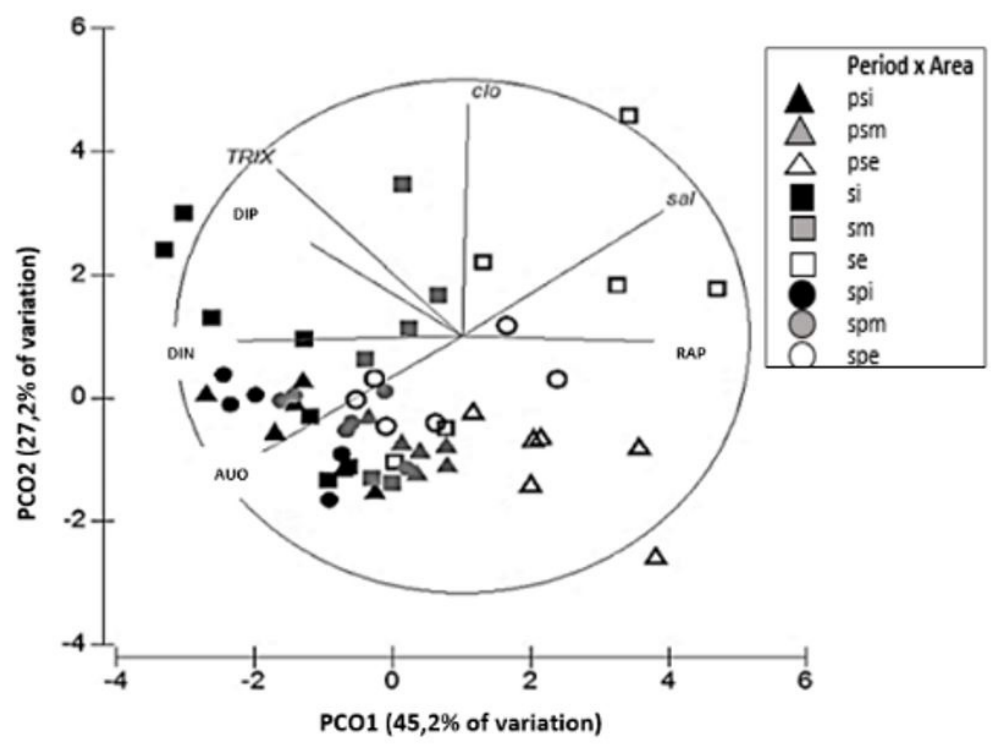

Figure 3. Graphic of the principal coordinates analysis (PCoA) with the variables used in TRIX and RAP equation, by sampling period and area of the Papaquara river. Source: Authors. 
of the internal and median areas. The samples of the external area were related to the highest concentration of salinity and better condition of RAP. However, the internal and median areas were related to the AOU, the DIN and DIP concentrations and TRIX values, which characterizes the eutrophication and worse environmental quality. The axis 2 described the temporal tendency, with the samples of summer period in the positive portion of the axis, which were correlated to the chlorophyll- $a$, salinity, TRIX and DIP, whereas the RAP wasn't representative for this axis.

The results pointed out a worsening in the trophic index of the Papaquara river during summer and post-summer periods in the median and external areas, whereas there was no modification in the RAP among the periods considered. This implies caution in the usage of the RAP as a tool to point the water quality of a determinate segment of the river. Despite the increase of the environmental condition in the external area, according to the RAP, it was observed a worsening of its water quality in the periods of high population pressure. It is expected that the biggest entrance of nutrients in the internal area of the watershed of the Papaquara river is affecting not only exactly, but all the system. The PAR and TRIX relation was effective for all the study area, but not in the exact scale or in the areas analyzed. The PAR, modified in this study to be applied in a river of coastal plain, showed in part the characteristics of the river that aren't modified in the temporal scale, for example the sinuosity, whereas $50 \%$ of its analysis enabled the observation of the changes in the seasonal scale, as water transparency and presence of macrophytes. This protocol has been useful as a low cost tool for environmental managers. So, new researches are necessary to better suit this protocol in the interpretation of water quality in systems similar to the one analyzed in this study.

The low water quality of the Papaquara river showed visible worsening in summer and post-summer periods, showing the neglect of the government in the application of the resources made, which makes a high amount with the summer tourism, but hardly invests to increase the water quality in this region. It is highlighted that the tourists come because of the natural landscape and water is an important coefficient. It is the government and organizations of environmental protection's responsibility to plan and work together in order to avoid or minimize the environmental impacts in the watershed of the Papaquara river.

\section{CONCLUSION}

The Rapid Assessment Protocol (RAP) was efficient to characterize the estuary water quality, when compared to the Trophic Index (TRIX), in the scale of the river, but not in the point scale or in its stretch. The Papaquara river showed eutrophic conditions due to the impacts from the internal area, more urbanized, with the worsening of the water quality during summer period. This condition remained in the system even after the departure of the temporary population, which reflected in post-summer. The urbanization, the inefficient wastewater treatment system, the usage of the PPA and of the river as a solid waste disposal are the main causes of the changes in the natural conditions of the aquatic system.

\section{ACKNOWLEDGEMENTS}

To CAPES for the master's degree scholarship. To INCT-TMCOcean (CNPq 484956/2012-4) for the financial support for the research. To the Estação Ecológica de Carijós for the data availability and for the field logistics. To the Laboratório Multiusuário - ECZ and Laboratório de Ficologia - LAFIC. To Alex Cabral, Alondra Perez, Arthur Gullar, Barbara Pereira, Débora Rodrigues and Denise Knisses for the collaboration in field and in the lab.

\section{REFERENCES}

ANDERSON, M. J. A new method for non-parametric multivariate analysis of variance. Austral Ecology, v. 26, p. 32-46, 2001.

ARAÚJO, A. M.; MELO, M. C. V. Um plano de amostragem de qualidade d'água em estuários: caso de Recife. Revista Brasileira de Recursos Hídricos, v. 5, n. 1, p. 111-120, 2000. http://dx.doi. org/10.21168/rbrh.v5n4.p111-120.

ARNOLD JUNIOR, C.; GIBBONS, C. J. Impervious surface coverage: the emergence of a key environmental indicator American Planning Association. Journal of the American Planning Association, v. 62, n. 2, p. 2, 1996. http://dx.doi.org/10.1080/01944369608975688.

BALDY, V.; TRÉMOLIÈRES, M.; ANDRIEU, M.; BELLIARD, $\mathrm{J}$. Changes in phosphorus content of two aquatic macrophytes according to water velocity, trophic status and time period in hardwater streams. Hydrobiologia, v. 575, n. 1, p. 343-351, 2007. http://dx.doi.org/10.1007/s10750-006-0380-0.

BIANCHINI JUNIOR, I. Modelos de crescimento e decomposição de macrófitas aquáticas. In: THOMAZ, S. M.; BINI, M. Ecologia e manejo de macrófitas aquáticas. Maringá: EDUEM, 2003. p. 85-126.

BOTELHO, R. G. M.; SILVA, A. S. Bacia hidrográfica e qualidade ambiental. In: VITTE, A. C.; GUERRA, A. J. T. Reflexões sobre a geografia física no Brasil. Rio de Janeiro: Bertrand Brasil, 2004.

BRASIL. Ministério do Turismo. Rio de Janeiro: primeira cidade em turismo de lazer. Brasília, 2013. Available from: < http://www. turismo.gov.br/turismo/noticias/todas_noticias/20130902.html > Access on: 31 jan. 2015.

BREGUNCE, D. T.; JORDAN, E. N.; DZIEDZIC, M.; MARANHO, L. T.; CUBAS, S. A. Avaliação da qualidade da água do Ribeirão dos Müller, Curitiba, PR. Revista Brasileira de Recursos Hídricos, v. 16, n. 3, p. 39-47, 2011.

BRICKER, S. B.; FERREIRA, J. G.; SIMAS, T. An integrated methodology for assessment of estuarine tropic status. Ecological 
Modelling, v. 169, n. 1, p. 39-60, 2003. http://dx.doi.org/10.1016/ S0304-3800(03)00199-6.

BRINSON, M.; RHEINHARDT, R.; FERRELL, R.; DUNCAN, B.; HOBBS, L.; MCNAUGHT, D.; PHELAN, J.; RADER, D. A rapid watershed assessment approach for protocol and case study. Ocean and Coastal Management, v. 71, p. 238-255, 2013. http://dx.doi. org/10.1016/j.ocecoaman.2012.08.006.

CALLISTO, M.; FERREIRA, W. R.; MORENO, P.; GOULART, M.; PETRUCIO, M. Aplicação de um protocolo de avaliação rápida da diversidade de hábitats em atividades de ensino e pesquisa (MG-RJ). Acta Limnologica Brasiliensia, v. 34, p. 91-97, 2002.

CAMPANÁRIO, P. Florianópolis: dinâmica demográfica e projeção da população por sexo, grupos etários, distritos e bairros (1950-2050). Florianópolis: Instituto de Planejamento de Florianópolis, 2007.

CERTI - FUNDAÇÃO CENTROS DE REFERÊNCIA EM TECNOLOGIAS INOVADORAS. Modelo e critérios para a estruturação do Corredor Ecológico Norte da Ilha, Florianópolis, Santa Catarina. Florianópolis: Socioambiental, 2010. (3 v.).

CHAMBERS, P. A. I.; PREPAS, E. E. Nutrient dynamics in riverbeds: the impact of sewage effluent and aquatic macrophytes. Water Research, v. 28, n. 2, p. 453-464, 1994. http://dx.doi. org/10.1016/0043-1354(94)90283-6.

CLOERN, J. E. Our evolving conceptual of the coastal eutrophication problem. Marine Ecology Progress Series, v. 210, p. 223-253, 2001. http://dx.doi.org/10.3354/meps210223.

COTOVICZ JUNIOR, L. C.; BRANDINI, N.; KNOPPERS, B. A.; FRIEDERICHS, W. Comparação de modelos e índices para avaliação do Estado Trófico do Complexo Estuarino-Lagunar Mundaú-Manguaba (AL). Geochimica Brasiliensis, v. 26, n. 1, p. 7-18, 2012.

CUDOWSKI, A. Dissolved reactive manganese as a new index determining the trophic status of limnic waters. Ecological Indicators, v. 48, p. 721-727, 2015. http://dx.doi.org/10.1016/j. ecolind.2014.09.035.

DHN - DIRETORIA DE HIDROGRAFIA E NAVEGAÇÃO. Tabua de marés. Porto do Açu, 2014. Available from: <http://www. mar.mil.br/dhn/chm/box-previsao-mare/tabuas/>. Access on: 10 dec. 2014.

FATMA - FUNDAÇÃO DO MEIO AMBIENTE DO ESTADO DE SANTA CATARINA. Licença Ambiental de Operação - LAI $n^{\circ}$ 175/09 - GELUR, 2009. Florianópolis. p. 38-39. Processo Administrativo ICMBio no ${ }^{\circ} 2078.000040 / 2011-44$.

FIDÉLIS FILHO, N. L. Uma abordagem sobre as profundas modificações na morfometria fluvial da bacia bidrográfica do rio Ratones - Florianópolis, SC, num período de quarenta anos e suas consequências. 1998. 255 f.
Dissertação (Mestrado em Engenharia Ambiental) - Universidade Federal de Santa Catarina, Florianópolis, 1998.

FIESC - FEDERAÇÃO DAS INDÚSTRIAS DO ESTADO DE SANTA CATARINA. Santa Catarina em dados. Florianópolis, 2014. Available from: <http://fiesc.com.br/sites/default/files/ medias/25_set_sc_dados_2014_em_baixa_para_site.pdf $>$. Access on: 24 sept. 2015 .

GRASSHOFF, K.; EHRARDT, M.; KREMELING, K. Methods of sea water analysis. 2nd ed. New York: Verlag Chemie, 1983. 317 p.

HANNAFORD, M. J.; BARBOUR, M. T.; RESH, V. H. Training reduces observer variability in visual-based assessments of stream habitat. Journal of the North American Benthological Society, v. 16, n. 4, p. 853-860, 1997. http://dx.doi.org/10.2307/1468176.

IBGE - INSTITUTO BRASILEIRO DE GEOGRAFIA E ESTATISTICA. Censo demográfico 2010. Rio de Janeiro, 2010. Available from: <http://censo2010.ibge.gov.br/>. Access on: 20 mar. 2014.

IPUF - INSTITUTO DE PLANEJAMENTO URBANO DE FLORIANÓPOLIS. Ortoimagem da Itha de Santa Catarina. Florianópolis, 2012. Available from: <http://geo.pmf.sc.gov. br/>. Access on: 8 june 2014 .

KANDZIORA, M.; BURKHARD, B.; MÜLLER, F. Interactions of ecosystem properties. ecosystem integrity and ecosystem service indicators: a theoretical matrix exercise. Ecological Indicators, v. 28, p. 54-78, 2013. http://dx.doi.org/10.1016/j.ecolind.2012.09.006.

LANDIM, P. M. B. Análise estatística de dados geológicos multivariados. São Paulo: Oficina de Textos, 2011.

LI, Y.; SHI, Y.; QURESHI, S.; BRUNS, A.; ZHU, X. Applying the concept of spatial resilience to socio-ecological systems in the urban wetland interface. Ecological Indicators, v. 42, p. 135-146, 2014. http://dx.doi.org/10.1016/j.ecolind.2013.09.032.

LOOY, K. V.; HONNAY, O.; PEDROLI, B.; MULLER, S. Order and disorder in the river continuum: the contribution of continuity and connectivity to floodplain meadow biodiversity. Journal of Biogeography, v. 33, n. 9, p. 1615-1627, 2006. http:// dx.doi.org/10.1111/j.1365-2699.2006.01536.x.

MINATTI-FERREIRA, D. D.; BEAUMORD, A. C. Adequação de um protocolo de avaliação rápida de integridade ambiental para ecossistemas de rios e riachos: aspectos físicos. Revista Saúde e Ambiente, v. 7, n. 1, p. 39-47, 2006.

MIZERKOWSKI, B. D.; MACHADO, E. C.; BRANDINI, N.; NAZARIO, M. G.; BONFIM, K. V. Environmental water quality assessment in Guaratuba Bay. State of Paraná, Southern Brazil. Brazilian Journal of Oceanography, v. 60, n. 2, p. 109-115, 2012. http:/ / dx.doi.org/10.1590/S1679-87592012000200001. 
MUFARREGE, M. M.; HADAD, H. R.; MAINE, M. A. Response of Pistia stratiotes to heavy metals (Cr, $\mathrm{Ni}$ and $\mathrm{Zn}$ ) and phosphorous. Archives of Environmental Contamination and Toxicology, v. 58, n. 1, p. 53-61, 2010. http://dx.doi.org/10.1007/s00244-009-9350-7. PMid:19506937.

NEAL, C.; JARVIE, H. P.; LOVE, A.; NEAL, M.; WICKHAM, H.; HARMAN, S. Water quality along a river continuum subject to point and diffuse sources. Journal of Hydrology, v. 350, n. 3-4, p. 154-165, 2008. http://dx.doi.org/10.1016/j.jhydrol.2007.10.034.

NOGUEIRA, F. M. B.; ESTEVES, F. A. Variação temporal da biomassa de duas espécies de macrófitas aquáticas em uma lagoa marginal do rio Mogi-Guaçu (SP). Acta Limnologica Brasiliensia, v. 3, p. 617-632, 1990.

PLAFKIN, J. L.; BARBOUR, M. T.; PORTER, K. D.; GROSS, S. K.; HUGHES, R. M. Rapid bioassessment protocols for use in streams and rivers: benthic macroinvertebrates and fish. United States Environmental Protection Agency, 1989. 179 p.

PORTO FILHO, E.; WASKOW, L. B.; DA SILVA, A. W. L.; SIERRA, E. J. S. Diagnóstico socioambiental e perspectivas de sustentabilidade para a região de entorno do rio Papaquara, Florianópolis/SC. In: CONGRESSO BRASILEIRO DE GESTÃO AMBIENTAL GOIÂNIA/GO, 3., 2012, Goiânia. Anais... Bauru: IBEAS, 2012.

QGIS DEVELOPMENT TEAM. QGIS Geographic Information System: Open Source Geospatial Foundation Project. [S.1.], 2015. Available from: <http:/ qgis.osgeo.org>. Access on: 10 apr. 2015.

R CORE TEAM. R: a language and environment for statistical computing. Vienna: R Foundation for Statistical Computing, 2015. Available from: < http://www.R-project.org/>. Access on: 8 june 2014 .

RABALAIS, N. N. R.; 'TURNER, E.; DÍAZ, R. J.; JUSTIC', D. Global change and eutrophication of coastal waters. Copenhagen: International Council for the Exploration of the Sea, 2009.

RANALLI, A. J.; MACALADY, D. L. The importance of the riparian zone and in-stream processes in nitrate attenuation in undisturbed and agricultural watersheds: a review of the scientific literature. Journal of Hydrology, v. 389, n. 3-4, p. 406-415, 2010. http://dx.doi.org/10.1016/j.jhydrol.2010.05.045.

RODRIGUES, A. S. L.; CASTRO, P. Protocolos de avaliação rápida: instrumentos complementares no monitoramento dos recursos hídricos. Revista Brasileira de Recursos Hídricos, v. 13, n. 1, p. 161-170, 2008. http://dx.doi.org/10.21168/rbrh.v13n1.p161-170.

SILVA, A. R.; KNIESS, D. C.; RIGOTTI, J. A.; FONSECA, A. L. D. Aplicação do modelo TRIX para avaliação da qualidade da água dos rios que drenam para Estação Ecológica de Carijós, Florianópolis, SC, Brasil. In: SIMPÓSIO BRASILEIRO DE
RECURSOS HÍDRICOS, 20., 2013, Bento Gonçalves. Anais... Bento Gonçalves: ABRH, 2013.

SILVA, C. A. R.; OLIVEIRA, S. R.; RÊGO, R. D. P.; MOZETO, A. A. Dynamics of phosphorus and nitrogen through litter fall and decomposition in a tropical mangrove florest. Marine Environmental Research, v. 64, n. 4, p. 524-534, 2007. http://dx.doi.org/10.1016/j. marenvres.2007.04.007. PMid:17599404.

SIMONASSI, J. C.; HENNEMANN, M. C.; TALGATTI, D.; MARQUES JUNIOR, A. N. Nutrient variations and coastal water quality of Santa Catarina Island, Brazil. Biotemas, v. 23, n. 1, p. 211-223, 2010.

SMITH, V. H.; TILMAN, G. D.; NEKOLA, J. C. Eutrophication: impacts of excess nutrient inputs on freshwater, marine and terrestrial ecosystems. Environmental Pollution, v. 100, n. 1-3, p. 179196, 1999. http://dx.doi.org/10.1016/S0269-7491(99)00091-3. PMid:15093117.

SOCIOAMBIENTAL. e.labore Assessoria Estratégica em Meio Ambiente. Estudo de Impacto Ambientale de Vizinhança do Sapiens Parque, Florianópolis. Florianópolis, 2004. (3 v.). Available from: <http:// www.sapiensparque.com.br/2009/index.php?option=com_conte $\mathrm{nt} \&$ view $=$ article\&id=148\&Itemid=143>. Access on: 10 jan. 2014.

STATHAM, P. J. Nutrients in estuaries: an overview and the potential impacts of climatic change. The Science of the Total Environment, v. 434, p. 213-227, 2012. http://dx.doi.org/10.1016/j. scitotenv.2011.09.088. PMid:22119025.

STRICKLAND, J. D. H.; PARSONS, T. R. A practical handbook of seawater analysis. Canada: Fisheries Research Board of Canada, 1972. $167 \mathrm{p}$.

TAVARES, J. L.; CALADO, A. L. A.; FONTES, F. C. Estudos iniciais para uso do índice TRIX para análise do nível de eutrofização no estuário do Rio Potengi - Natal - RN - Brasil. Revista AIDIS de Ingeniería y Ciencias Ambientales: Investigación, Desarrollo y Práctica, v. 7, n. 3, p. 297-308, 2014.

TRATA BRASIL. Saneamento, saúde, educação e turismo: o caso Santa Catarina. Coordenação Marcelo Côrtes Neri. Rio de Janeiro: FGV/ IBRE, CPS, 2008.

VARGAS, J. R. A.; FERREIRA JÚNIOR, P. D. Aplicação de um protocolo de avaliação rápida na caracterização da qualidade ambiental de duas Microbacias do Rio Guandu, Afonso Cláudio, ES. Revista Brasileira de Recursos Hidricos, v. 17, n. 1, p. 161-168, 2012. http://dx.doi.org/10.21168/rbrh.v17n1.p161-16.

VILLATE, F.; IRIARTE, A.; URIARTE, I.; INTXAUSTI, L.; DE LA SOTA, A. Dissolved oxygen in the rehabilitation phase of an estuary: Influence of sewage pollution abatement and hydroclimatic factors. Marine Pollution Bulletin, v. 70, n. 1-2, p. 234-246, 
2013. http://dx.doi.org/10.1016/j.marpolbul.2013.03.010. PMid:23601887.

VOLLENWEIDER, R. A.; GIOVANARDI, F.; MONTANARI, G.; RINALDI, A. Characterization of the trophic conditions of marine coastal waters with special reference to the $\mathrm{Nw}$ Adriatic Sea: proposal for a trophic scale. turbidity and generalized water quality index. Environmetrics, v. 9, n. 9, p. 329-357, 1998. http:// dx.doi.org/10.1002/(SICI)1099-095X(199805/06)9:3<329::AIDENV308>3.0.CO;2-9.

WITHERS, P. J. A.; JARVIE, H. P. Delivery and cycling of phosphorus in rivers: a review. The Science of the Total Environment, v. 400, n. $1-3$, p. 379-395, 2008. http://dx.doi.org/10.1016/j. scitotenv.2008.08.002. PMid:18804845.

\section{Authors contributions}

Aichely Rodrigues da Silva: responsible for laboratory tests, development of a Rapid Assessment Protocol, application of the trophic index, realization of statistical analysis, analysis of results, discussions and conceived the paper and wrote the manuscript draft.

Alessandra Larissa D' Oliveira Fonseca: advisor and conceived the paper and contributed to the development of the work in general and helped writing the final version of paper.

Claudinei José Rodrigues: support for laboratory analysis.

Ângela da Veiga Beltrame: advisement in the application of the trophic index. 